\title{
Development of a Direct Drive Permanent Magnet Generator for Small Wind Turbines
}

\author{
Final Technical Report for the U.S. Department of Energy \\ Grant Number DE-FG36-03G013139
}

Reporting Period: 09/30/2003 - 09/30/2004

DOE Project Officer: Keith Bennett

TIAX Project Director: Paul McTaggart

Phone Number: 617-498-5847

Fax Number: $617-498-7275$

E-Mail: mctaggart.p@tiaxllc.com

January 7, 2005

Report prepared by: Allan Chertok and David Hablanian

TIAX LLC

15 Acorn Park

Cambridge, MA

02140-2390

TIAX Reference: D0223

This report was prepared as an account of work sponsored by an agency of the United States Government. Neither the United States government nor any agency thereof, or any of its contractors/subcontractors, or any of their employees, makes any warranty, express or implied, or assumes any legal liability or responsibility for the accuracy, completeness, or usefulness of any information, apparatus, product, or process disclosed, or represents that its use would not infringe privately owned rights. Reference herein to any specific commercial product, process, or service by trade name, trademark, manufacturer, or otherwise, does not necessarily constitute or imply its endorsement, recommendation, or favoring by the United States Government or any agency thereof. The views and opinions of authors expressed herein do not necessarily state or reflect those of the United States Government or any agency thereof. 


\section{Table of Contents}

2.0 TECHNICAL TASKS............................................................................................. 2-2

2.1 TASK 1 - SPECIFICATION OF DESIGN REQUIREMENTS ………….............................................. 2-3

2.2 TASK 2 - PARAMETRIC CAD MODEL OF ARMATURE AND FIELD GEOMETRY .......................... 2-4

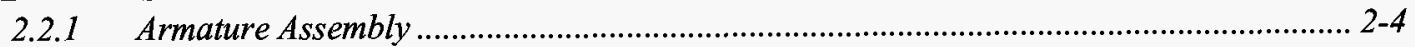

2.2.2 Armature Coil Construction ........................................................................................ 2-6

2.2.3 Field Magnet Assembly ................................................................................................. 2-7

2.2.4 Illustrative Integration of Generator and Wind Turbine ................................................ 2-8

2.3 TASK 3 - MATHCAD MODEL PARAMETRIC ANALYSIS .......................................................... 2-9

2.3.1 Winding Configuration............................................................................................... 2-9

2.3.2 MathCAD Procedure Design Results ............................................................................. 2-9

2.4 TASK 4 - MAGNETO MODEL ANALYSIS ………................................................................ 2-11

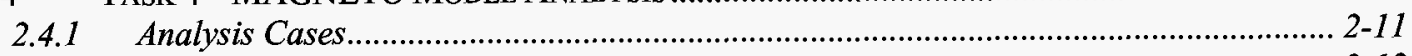

2.4.2 Leveraging Model Symmetry ..................................................................................... 2-12

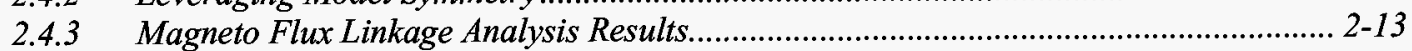

2.4.4 Magneto Cogging Torque Analysis Results ................................................................. 2-14

2.4.5 Magneto Electromagnetic Reaction Torque Analysis Results........................................ 2-14

2.5 TASK 5 - PREPARE DRAWING PACKAGE ………................................................................ 2-16

2.6 TASK 6 - EXTRAPOLATE RESULTS ............................................................................... 2-17

2.7 TASK 7 - Preliminary MANUfacturing Cost ANALYSIS AND POWER EleCtronic System

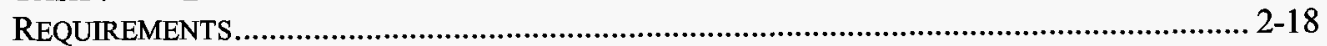

2.7.1 Factory Cost Analysis ................................................................................................ 2-18

2.7.2 Analysis of Manufacturing Cost Sensitivity to Production Rate ..................................... 2-18

2.7.3 Extrapolation of Manufacturing Cost to smaller and larger ratings ............................... 2-19

2.7.4 Comparable Manufacturing Cost for a Conventional Non-Modular PMG ..................... 2-20

2.7.5 Power Electronic System Requirements..................................................................... 2-21

$2.8 \quad$ ANNUAL COST SAVINGS ....................................................................................... 2-22

3.0 CONCLUSIONS AND RECOMMENDATIONS........................................................... 3-1

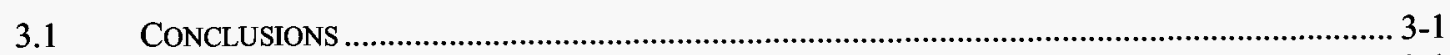

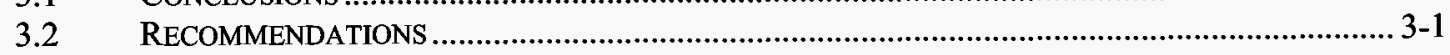

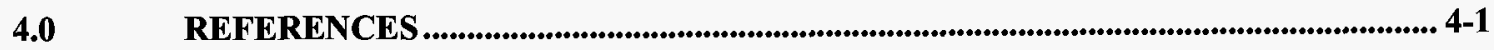




\section{List of Tables}

Table 1: Program Schedule........................................................................................ 2-2

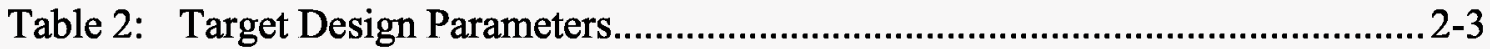

Table 3: MathCAD Model Inputs and Outputs ......................................................... 2-9

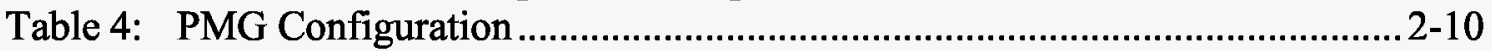

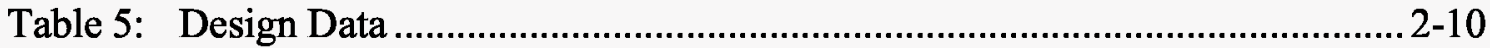

Table 6: Configurations for 25 and $100 \mathrm{~kW}$ Sizes ................................................... 2-17

Table 7: Manufacturing Costs as A Function of Power Rating................................. 2-19

Table 8: Non-Modular $50 \mathrm{~kW}$ Design Configuration.............................................2-20

Table 9: Modular/Non-Modular Costs ............................................................... 2-20

Table 10: Characteristics of Bergey XL.50 and TIAX's Design.............................2-21 


\section{List of Figures}

Figure 1: 2D Section View of Armature ............................................................ 2-5

Figure 2: Solid Model of Armature and Field Geometry ........................................ 2-5

Figure 3: Armature Coil Construction.............................................................. 2-7

Figure 4: Magnets and Backiron Plate .............................................................. 2-8

Figure 5: PMG packaging and integration with other Wind Turbine Components .... 2-8

Figure 6: Partial View of Modeled Section ....................................................... 2-12

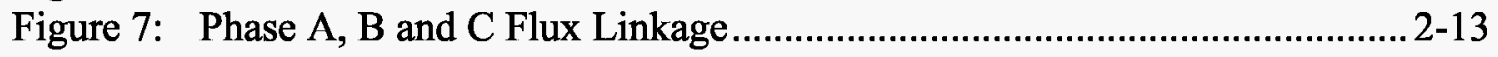

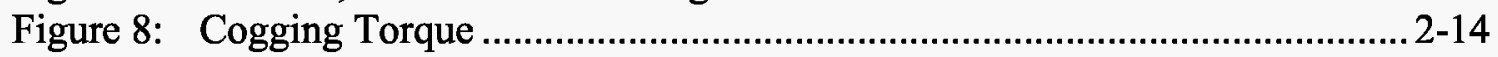

Figure 9: Electromagnetic Reaction Torque Ripple ............................................ 2-15

Figure 10: Pro/E Drawings of Armature, Field, and Packaging...............................2-16

Figure 11: Factory Cost Analysis .................................................................... 2-18

Figure 12: Sensitivity of Manufacturing Cost to Production Rate ............................ 2-19 


\section{Executive Summary}

In this program, TIAX performed the conceptual design and analysis of an innovative, modular, direct-drive permanent magnet generator (PMG) for use in small wind turbines that range in power rating from $25 \mathrm{~kW}$ to $100 \mathrm{~kW}^{1}$. TIAX adapted an approach that has been successfully demonstrated in high volume consumer products such as direct-drive washing machines and portable generators. ${ }^{2}$ An electromagnetic model was created and the modular PMG design was compared to an illustrative non-modular design. The resulting projections show that the modular design can achieve significant reductions in size, weight, and manufacturing cost without compromising efficiency. Reducing generator size and weight can also lower the size and weight of other wind turbine components and hence their manufacturing cost.

\footnotetext{
${ }^{1}$ Related DOE investigations of larger MW-scale direct drive generators have been reported by others [7].
}

${ }^{2}$ Fisher-Paykel direct drive veritcal axis clothes washing machine and Honda variable speed portable generator sets 


\subsection{Introduction}

The objective of this project was to design and assess an improved Direct Drive Permanent Magnet Generator (DD PMG) architecture for use in small wind turbines ranging from $25 \mathrm{~kW}$ to $100 \mathrm{~kW}$ in size. In this work TIAX adapted an existing permanent magnet motor/generator architecture now employed in mass-produced consumer products to the wind-turbine application with the objective of reducing the size, weight and manufacturing cost of the generator without compromising efficiency.

Reducing generator size and weight can also lower size and weight of other wind turbine components and hence their manufacturing cost. TIAX also believes that the robust winding insulation system employed in its design will also reduce the likelihood of generator failure and avoid costly repair and lost productivity. It is expected that reduction of manufacturing cost, repair cost and lost productivity will promote use of small wind turbines in low wind speed regions. In summary the benefits are as follows:

- Reduced wind turbine installed cost

- Lower first cost of generator component

- Lighter weight PMG lowers tower and foundation cost

- Reduced O\&M Cost

- More reliable insulation - fewer repairs, higher availability

- Modularity facilitates repairs and lowers repair cost

- Improved efficiency

- Lower copper loss

During the course of this work TIAX developed an innovative PMG concept to meet the objectives of reducing size, weight and cost - and improving winding insulation reliability. Salient aspects of the TIAX design concept include:

- External rotor configuration

- Minimize armature size, weight and cost

- Avoid tensile loading of magnet bonds

- Fractional slot armature winding

- Low slots/pole/phase to avoid overlapping end turns

- Enable armature modularity

- Minimize end turn copper loss

- Modular armature construction ${ }^{3}$

- Precisely wound coils

- Plastic moldings to accurately and robustly insulate and integrate components

\footnotetext{
${ }^{3}$ Modular armature construction employing soft ferromagnet composite core construction for smaller scale, internal rotor machines has been investigated by A.G. Jack et al. [8]
} 


\subsection{Technical Tasks}

To accomplish the objectives of the program, TIAX LLC performed a project comprising several major tasks. The tasks and the program schedule are shown in Table 1 . The completion of these tasks established that the technological approach was feasible in the relevant size range. The program also identified the key cost and performance characteristics. The general approach was a "paper design" supported by engineering analysis to understand and characterize the design. To provide a comparison with conventional, established designs, a simplified, limited design activity was conducted with respect to a conventional surface magnet PMG design of comparable power, speed and efficiency ratings. The latter design was developed only to the extent needed to provide comparative information and not to the point of being a fully developed concept. Throughout these tasks, the focus was on the demonstration of concept feasibility to serve as a basis for future design phases. As a result, the activities were designed to explore central issues bearing on the feasibility of the proposed technology and approach and the program was not designed to produce a final design ready for production and field application.

\section{Table 1: Program Schedule}

\begin{tabular}{|c|c|c|c|c|c|c|c|c|c|c|c|c|c|c|c|}
\hline \multirow{2}{*}{ test? } & \multicolumn{3}{|c|}{2008} & \multicolumn{12}{|c|}{200} \\
\hline & 0 & $\mathbf{N}$ & D & $\mathbf{J}$ & & $\mathbf{M}$ & A & $\mathbf{M}$ & J & J & & s & o & & D \\
\hline 1. Requirements Specification & & & & & & & & & & & & & & & \\
\hline 2. Develop Parametric Model & & & & & & & & & & & & & & & \\
\hline 3. Perform Parametric Analysis & & & & & & & & & & & & & & & \\
\hline 4. Perform Boundary Element Analysis & & & & & & & & & & & & & & & \\
\hline 5. Prepare Drawing Package & & & & & & & & & & & & & & & \\
\hline 6. Extrapolate Results & & & & & & & & & & & & & & & \\
\hline 7. Manufacturing Cost Analysis & & & & & & & & & & & & & & & \\
\hline
\end{tabular}




\subsection{Task 1 - Specification of Design Requirements}

Design requirements presented at the kickoff teleconference (October 24, 2003) were adjusted as a result of suggestions made by the NREL technical advisors.

- Rated speed decreased from 110 to $100 \mathrm{rpm}$

- Better match to prospective $50 \mathrm{~kW}$ turbine application

- Lower speed preferred to minimize blade noise

- Winding current density decreased from 800 to $600 \mathrm{~A} / \mathrm{cm}^{2}$

- Avoid potential difficulty with managing copper losses

- Loss proportional to square of current density

- Subsequently adopted a $400 \mathrm{a} / \mathrm{cm}^{2}$ value to achieve efficiency and synchronous reactance goals

Target design parameters identified in Table 2 were selected for a $50 \mathrm{~kW}$ unit. ${ }^{4}$

Table 2: Target Design Parameters

\begin{tabular}{|c|c|c|c|c|c|}
\hline Parameter & Term & Value & Units & Notes & Ref. \\
\hline Rated Speed & $\Omega_{\mathrm{r}}$ & 100 & rpm & $\begin{array}{l}\text { Comparable to Bergey } \\
\text { XL50 }\end{array}$ & \\
\hline Maximum Speed & $\Omega_{\mathrm{m}}$ & 1.5 & $\mathrm{pu}$ & $\begin{array}{l}\text { Accommodate VS mode } \\
\text { and overspeeding }\end{array}$ & \\
\hline $\begin{array}{l}\text { Rated Power } \\
\text { Efficiency }\end{array}$ & $e_{r}$ & 94 & $\%$ & $\begin{array}{l}\text { Deemed feasible at viable } \\
\text { size, weight } \& \text { cost }\end{array}$ & \\
\hline $\begin{array}{l}\text { Rated Speed Open } \\
\text { Circuit Voltage }\end{array}$ & $V_{r}$ & 600 & $V_{\text {rms }}$ L-L & $\begin{array}{l}\text { Limit } \mathrm{V} \text { to } 600 \mathrm{~V}, \\
\text { accommodate } 1,200 \mathrm{~V} \\
\text { IGBTs }\end{array}$ & \\
\hline $\begin{array}{l}\text { Rated Speed } \\
\text { Reactance }\end{array}$ & $X_{r}$ & 0.5 & $\mathrm{pu}$ & $\begin{array}{l}\text { Target assuming active } \\
\text { rectifier }\end{array}$ & [4] \\
\hline $\begin{array}{l}\text { Armature Conductor } \\
\text { Current Density }\end{array}$ & $\mathrm{J}_{\mathrm{a}}$ & 400 & $\mathrm{~A} / \mathrm{cm}^{2}$ & $\begin{array}{l}\text { Suitable for available forced } \\
\text { air cooling }\end{array}$ & [2], [3] \\
\hline $\begin{array}{l}\text { Armature Winding Fill } \\
\text { Factor }\end{array}$ & & 70 & $\%$ & $\begin{array}{l}\text { Achievable with bobbin } \\
\text { wound coils }\end{array}$ & \\
\hline $\begin{array}{l}\text { Magnet Energy } \\
\text { Product }\end{array}$ & $U_{m}$ & $28-35$ & MGOe & $\begin{array}{l}\text { Range of sintererd NdFeB } \\
\text { deemed affordable }\end{array}$ & \\
\hline $\begin{array}{l}\text { Stator Iron Specific } \\
\text { Loss }\end{array}$ & $p_{c}$ & 3.2 & W/lbm & $\begin{array}{l}@ 10 \text { kG-24 Ga, M-45 } \\
\text { anticipated acceptable }\end{array}$ & [1] \\
\hline Magnet Unit Cost & $c_{m}$ & 30 & \$/lbm & Preliminary estimate & \\
\hline Stator iron Unit Cost & $\mathrm{C}_{\mathrm{si}}$ & 3.00 & $\$ / / \mathrm{bm}$ & Preliminary estimate & \\
\hline Copper Coil Unit Cost & $\mathrm{C}_{\mathrm{cu}}$ & 3.00 & $\$ / \mathrm{lbm}$ & Preliminary estimate & \\
\hline
\end{tabular}

${ }^{4}$ The winding fill factor target was established after the kickoff teleconference. Feasibility of achieving at least this value $(70 \%)$ was confirmed by a detailed geometric layout of the armature core, bobbin and coil cross-section for the illustrative $50 \mathrm{~kW}$ design described herein. Somewhat higher fill factor can be achieved by adding coil turns constituting a partial winding layer. Note, too, that PMG manufacturing cost estimates were ultimately determined using vendor provided stator iron, magnet and coil winding costs rather than by application of the unit costs assumed in Table 2. 


\subsection{Task 2 - Parametric CAD Model of Armature and Field Geometry}

A 3D CAD model was created using Pro/Engineer ${ }^{\mathrm{TM}}$ to facilitate electromagnetic model geometry definition and mechanical design and development of assembly features.

Results of this effort included:

- $\mathrm{A} 2 \mathrm{D}$ axial section view

- Parameterized details corresponding to variables of PMG design procedure

- Extracted additional dimensions for a discrete element magnetic analysis model

- Development of modular armature structure

- Core module and module assembly concept

- Winding module and terminations - validation of estimated copper fill factor

- Insulation and encapsulation system concept

- Illustration of potential packaging concepts for wind turbine integration

The 2D view provided required dimensions for the subsequent magnetic field and analysis model.

\subsubsection{Armature Assembly}

The armature assembly consists of a laminated steel core fitted with bobbin wound coils. ${ }^{5}$ The core is assembled from modular packs of laminations and is secured to a central aluminum hub with threaded fasteners and nut plates fitted in core back iron apertures. ${ }^{6}$ Piloting features and other design details are incorporated to facilitate a robust and precise assembly of these modular units as depicted in Figures 1 and 2.

\footnotetext{
${ }^{5}$ As the fundamental core flux frequency is relatively low - e.g., $37 \mathrm{~Hz}$ at $100 \mathrm{rpm}$ for an illustrative $50 \mathrm{~kW}$ rating, acceptable core loss can be achieved with low-cost M45, non-oriented motor lamination steel. M45, 24 gauge $(0.025$ " thick) steel was assumed for the manufacturing cost analyses.

${ }^{6}$ Stainless steel fasteners and nut plates with high resistivity would be employed to avoid significant eddy current heat induction due to motional and alternating magnetic fields in the fastener region of the core back iron. Finite element analyses of eddy current induction loss and torque production impact of these back iron fasteners would be conducted as part of the detailed design of a prototype machine - for cases of non-magnetic and magnetic stainless steel alloys. TIAX experience with permanent magnet linear motion machines suggests that a magnetic type Carpenter 430FR stainless steel may be a good candidate.
} 


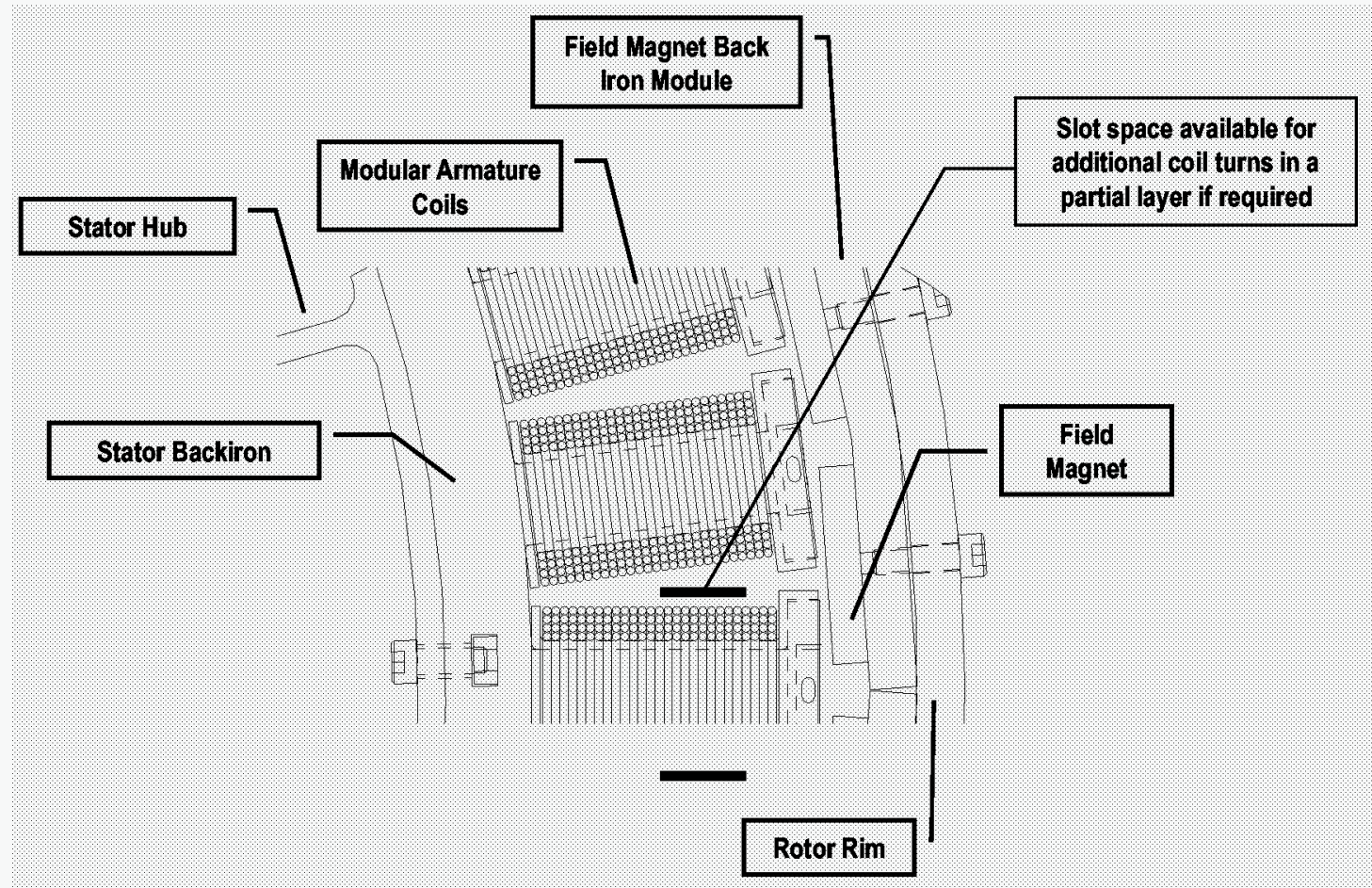

Figure 1: 2D Section View of Armature

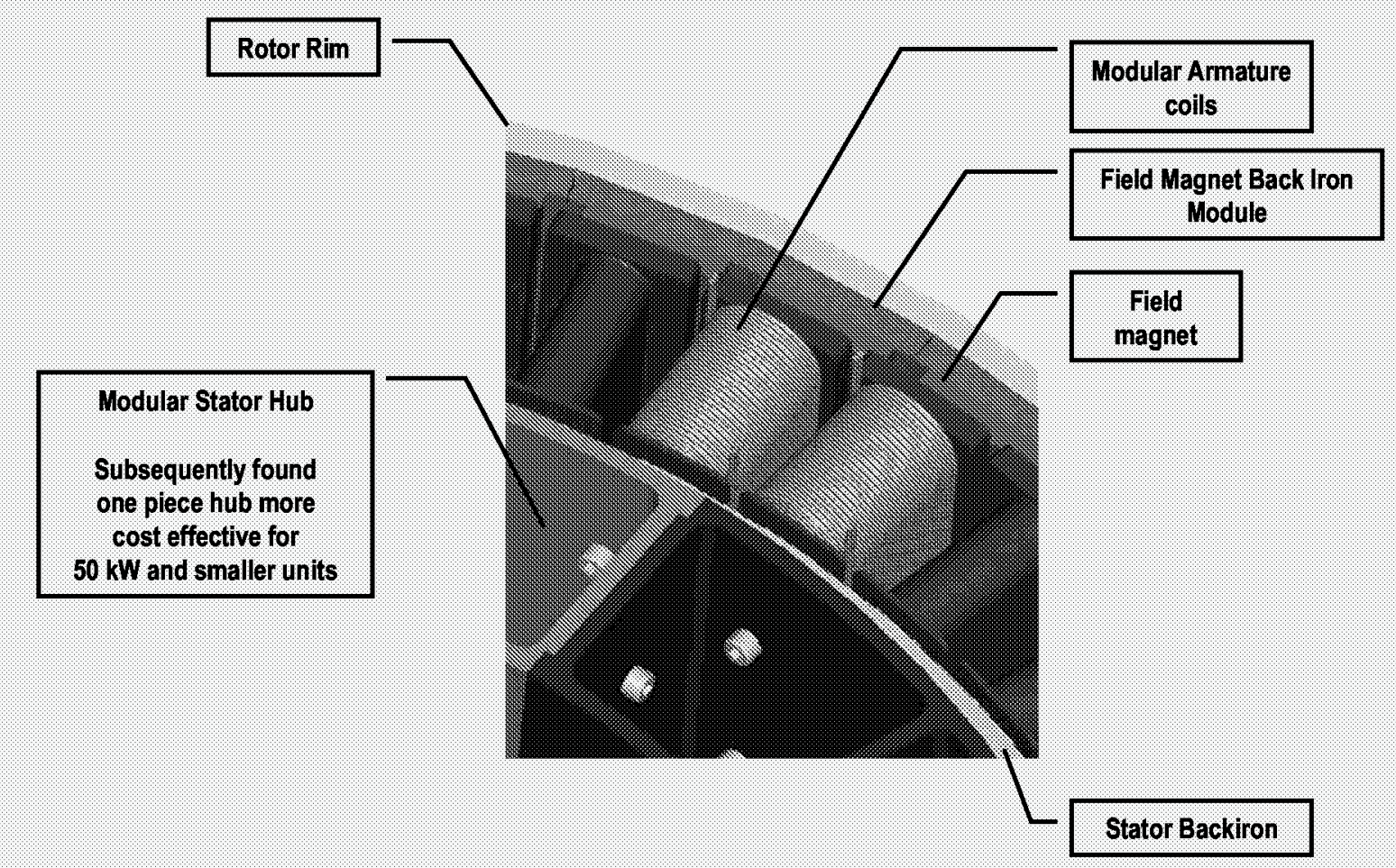

Figure 2: Solid Model of Armature and Field Geometry 


\subsubsection{Armature Coil Construction}

Armature coils were designed to be precisely wound on molded bobbins as depicted in Figure 3. Bobbin material with high thermal conductivity will be selected to facilitate conduction of coil copper dissipation to the armature core tooth and ultimately to air cooled wind turbine structure serving as a heat sink New high thermal conductivity plastic formulations by Cool Polymers Inc., Warwick RI, are potential candidates for this purpose. Square or rectangular wire (with rounded corners) could be used to increase fill factor and thereby reduce copper loss.

\section{Advantages:}

- High degree of ground wall insulation

- Precisely fitted turns

- High fill factor 70\%

- Controlled voltage gradient across start to finish turns

- Precise control of encapsulation

- Dips and bakes, or

- Vacuum pressure injection, or

- Injection molding

- Avoid need for large encapsulation tank 


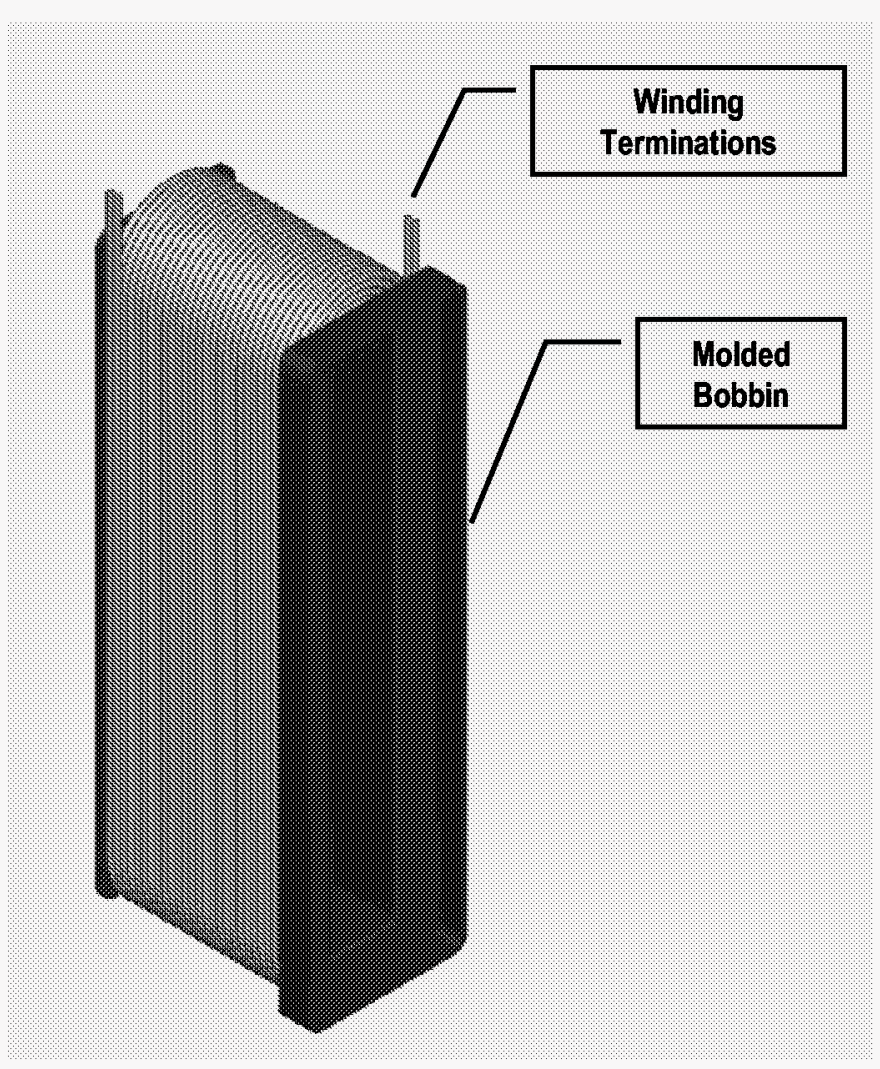

Figure 3: Armature Coil Construction

\subsubsection{Field Magnet Assembly}

Rectangular prismatic field magnets of sintered neodymium iron boron (NdFeB) material are configured for bonding to a pressed steel backiron plate (one per pole pair) as illustrated in Figure 4.

\section{Advantages:}

- External rotor configuration

- Avoids magnet bond centrifugal load

- Permits flat faced magnets

- Least cost rectangular prism magnets

- Pole employs one or more segments

- Ease of modular assembly/disassembly

- Pretest and qualify modules before final machine assembly

- Modules can be installed after rotor is mated with stator - avoid need for very large and stiff assembly/disassembly fixture 


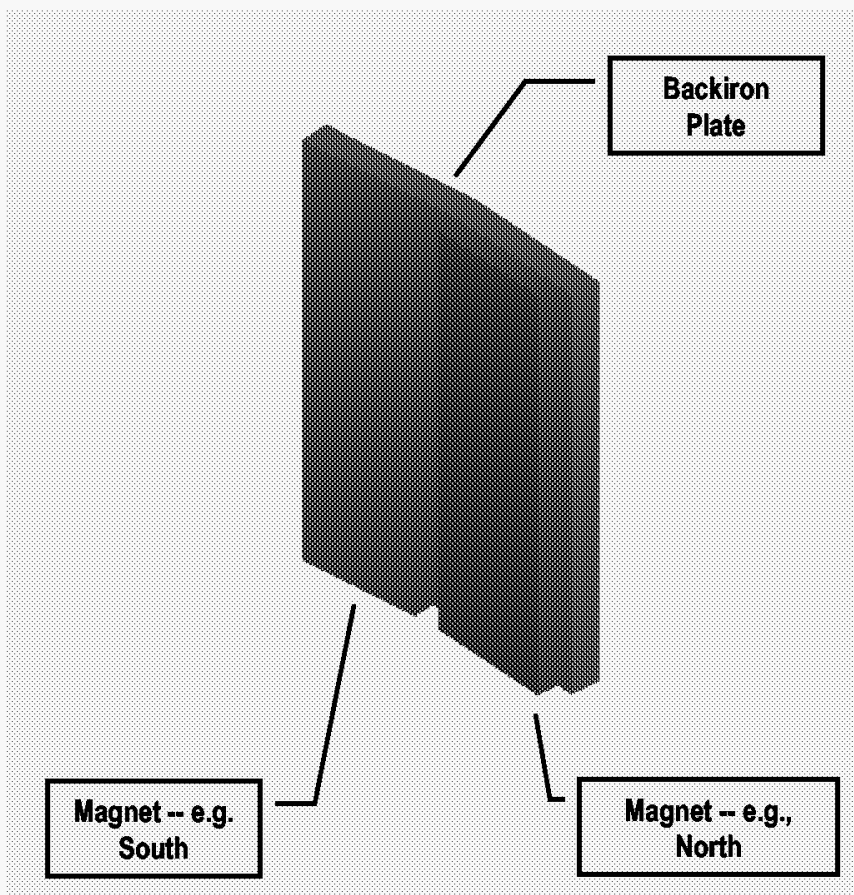

Figure 4: Magnets and Backiron Plate

\subsubsection{Illustrative Integration of Generator and Wind Turbine}

Parametric modeling was extended to include depiction of illustrative PMG packaging and integration with other turbine components as depicted in Figure 5.

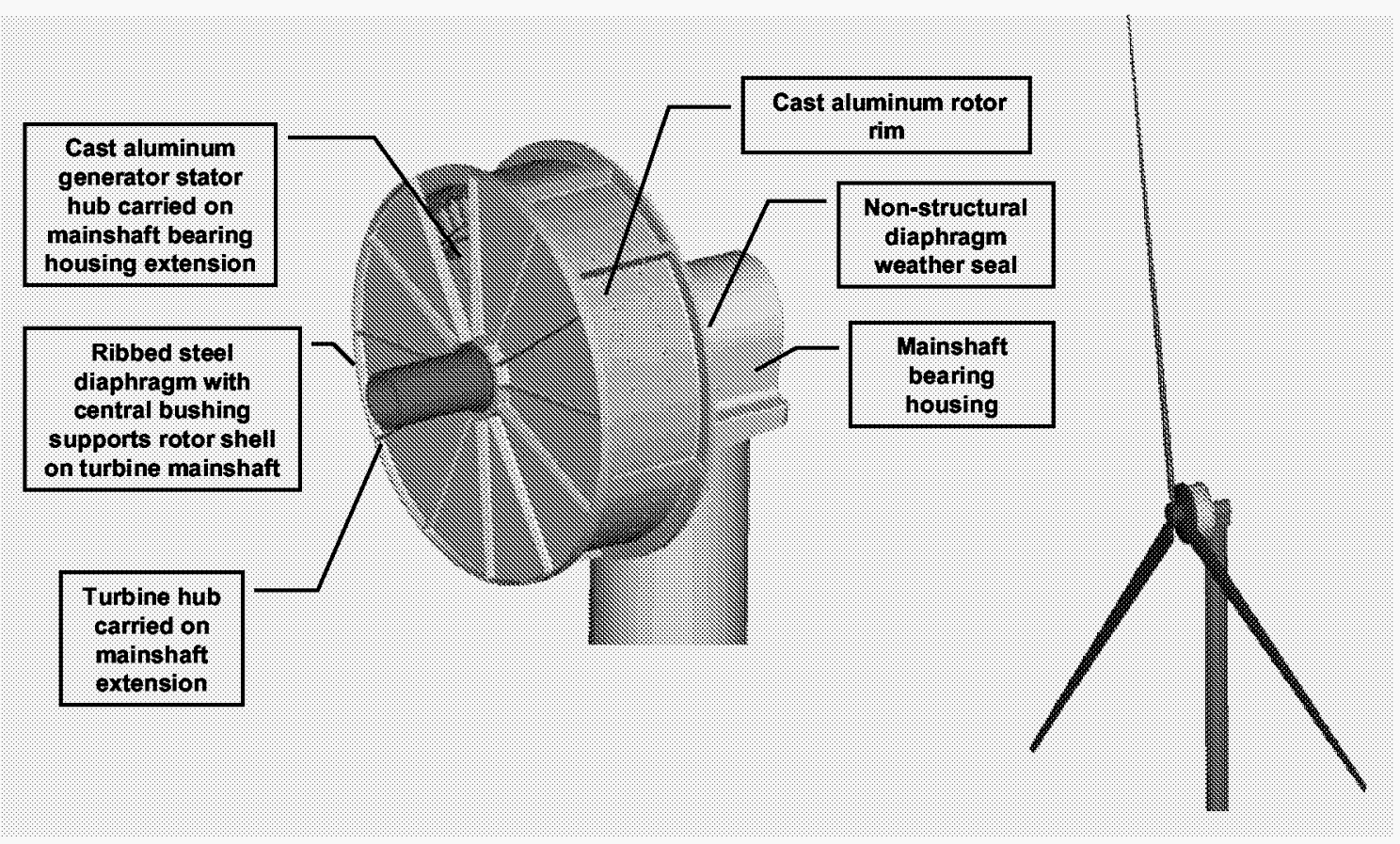

Figure 5: PMG packaging and integration with other Wind Turbine Components 


\subsection{Task 3 - MathCAD Model Parametric Analysis}

Our MathCAD based design procedure for permanent magnet electrical machinery was used to quickly minimum size, weight and cost configuration. Salient MathCAD procedure inputs and outputs are identified in Table 3.

Table 3: MathCAD Model Inputs and Outputs

\begin{tabular}{|l|l|}
\hline \multicolumn{1}{|c|}{ Inputs } & \multicolumn{1}{c|}{ Examples } \\
\hline Required operating parameters & Speed, power, open circuit voltage \\
\hline Geometry & Slot, tooth, backiron and magnet dimensions \\
\hline Winding configuration & Phase number, slots/pole/phase \\
\hline Allowables & $\begin{array}{l}\text { Wire current density, maximum core flux } \\
\text { density }\end{array}$ \\
\hline Material properties & Magnet, core and copper \\
\hline
\end{tabular}

\begin{tabular}{|l|l|}
\hline \multicolumn{1}{|c|}{ Outputs } & \multicolumn{1}{c|}{ Examples } \\
\hline Achieved operating parameters & Torque, reactance, copper and iron losses \\
\hline Figures of merit & Size, weight \\
\hline
\end{tabular}

\subsubsection{Winding Configuration}

A fractional slot armature winding was adopted to achieve a lower cost and higher efficiency modular design.

- Benefit

- Fractional slot designs with low number of slots per pole per phase (spp) avoid overlapping end turns enabling armature modularity with minimum copper loss

- Tradeoffs

- Fractional slot windings are used to suppress magnetomotive force (mmf) harmonics but those with a relatively low spp may add sub-harmonic components which increase synchronous reactance

- Synchronous reactance limiting of power delivery capability may be overcome by capacitor compensation or use of an active rectifier which offers additional benefits - e.g., drive generator as motor to assist stall controlled turbine start up

- SPP selection criteria to achieve best result

- Enable armature modularity

- Acceptable synchronous reactance

- Favorable component dimensions

\subsubsection{MathCAD Procedure Design Results}

A PMG configuration closely meeting the target requirements was determined by iterations of the MathCAD design procedure. Inputs and outputs are shown in Table 4. 
Table 4: PMG Configuration

\begin{tabular}{|c|c|c|c|}
\hline \multirow{11}{*}{ Key Inputs } & Parameter & Value & Units \\
\hline & Speed & 100 & Rpm \\
\hline & Power & 50 & $\mathrm{~kW}$ \\
\hline & Air Gap width & 3.0 & $\mathrm{~mm}$ \\
\hline & Air Gap Diameter & 0.8 & $\mathrm{~m}$ \\
\hline & Air Gap Length & 0.16 & $\mathrm{~m}$ \\
\hline & Current Density & 400 & $\mathrm{~A} / \mathrm{cm}^{2}$ \\
\hline & Core Flux Density & 1.8 & $\mathrm{~T} \max$ \\
\hline & Magnet $\mathrm{Br}$ & 11,000 & $\mathbf{G}$ \\
\hline & Magnet $\mathrm{Hc}$ & 10,200 & $\mathrm{Oe}$ \\
\hline & Core & 24 & Ga, M45 \\
\hline \multirow{3}{*}{ Key Outputs } & Efficiency & 95.6 & $\%$ \\
\hline & Synchronous Reactance $^{1}$ & 0.68 & $\mathrm{pu}$ \\
\hline & Weight (EM Materials) & 228 & $\mathrm{~kg}$ \\
\hline
\end{tabular}

${ }^{1}$ Value is greater than the 0.5 pu goal but acceptable if compensated

Other important design data were determined by the MathCAD design tool and are identified in Table 5.

Table 5: Design Data

\begin{tabular}{|c|c|c|c|}
\hline \multirow{4}{*}{ Winding } & Parameter & Value & Units \\
\hline & $\begin{array}{l}\text { Winding Factor for } \\
\text { Synchronous Wave }\end{array}$ & 0.95 & \\
\hline & Copper Loss & 2,100 & W at rated power \\
\hline & Open Circuit Voltage & 486 & $\begin{array}{c}\mathrm{V}_{\text {rms }} \text { line-line at } 100 \\
\mathrm{rpm}\end{array}$ \\
\hline \multirow{5}{*}{$\begin{array}{l}\text { Electromagnetic } \\
\text { Material }\end{array}$} & $\begin{array}{l}\text { Armature Core } \\
\text { Weight }\end{array}$ & 115 & $\mathrm{~kg}$ \\
\hline & Copper Weight & 58 & $\mathrm{~kg}$ \\
\hline & Magnet Weight & 22 & $\mathrm{~kg}$ \\
\hline & $\begin{array}{l}\text { Magnet Back Iron } \\
\text { Weight }\end{array}$ & 33 & $\mathrm{~kg}$ \\
\hline & Core Loss & 215 & W at $100 \mathrm{rpm}$ \\
\hline \multirow{3}{*}{ Other } & Air Gap Flux Density & 0.8 & $\mathrm{~T}$ \\
\hline & $\begin{array}{l}\text { Armature Current } \\
\text { Loading }\end{array}$ & 74 & $\mathrm{kA} / \mathrm{m}$ \\
\hline & $\begin{array}{l}\text { Tractive Force } \\
\text { Density }\end{array}$ & 33 & $\mathrm{kN} / \mathrm{m}^{2}$ \\
\hline
\end{tabular}

Copper loss is dominant and amounts to $4.2 \%$ of the $50 \mathrm{~kW}$ rating. Due to the low core flux frequency (e.g., $37 \mathrm{~Hz}$ at $100 \mathrm{rpm}$ ) the core loss is quite small - even with the assumed low-cost M45 lamination steel -- amounting to only $0.4 \%$ of the $50 \mathrm{~kW}$ rating. Additional, relatively small loss components, may be expected - e.g., in fasteners used to secure the armature core to the machine hub. Sub-harmonic components of the air gap mmf associated with the low $\mathrm{q}$ fractional slot windings employed in this design have potential to induce eddy current losses in the field magnets, magnet back iron and back iron fasteners. These additional loss components and means to suppress them would be investigated by TIAX prior to fabrication of a prototype unit. 


\subsection{Task 4 - MAGNETO Model Analysis}

\subsubsection{Analysis Cases}

A Magneto 2D boundary element model was constructed and several key analysis cases were conducted. The approach is described below.

- Rationale

- Verify open circuit voltage predicted by MathCAD procedure

- Verify reaction torque predicted by MathCAD procedure

- Assess cogging torque and electromagnetic torque ripple

- Identify power limitation due to core saturation and assess compensating adjustments

- Method

- Use Pro/Engineer design to define Magneto model dimensions

- Assign core and magnet properties

- Define slot currents as a function of rotor position

- Analysis Cases

- Open circuit coil flux linkage and voltage - without slot currents

- Reaction torque as a function of rotor position 


\subsubsection{Leveraging Model Symmetry}

We modeled only a portion of the PMG, taking advantage of symmetry to minimize solution time for each case. A partial view of the Magneto model is depicted in Figure 6.

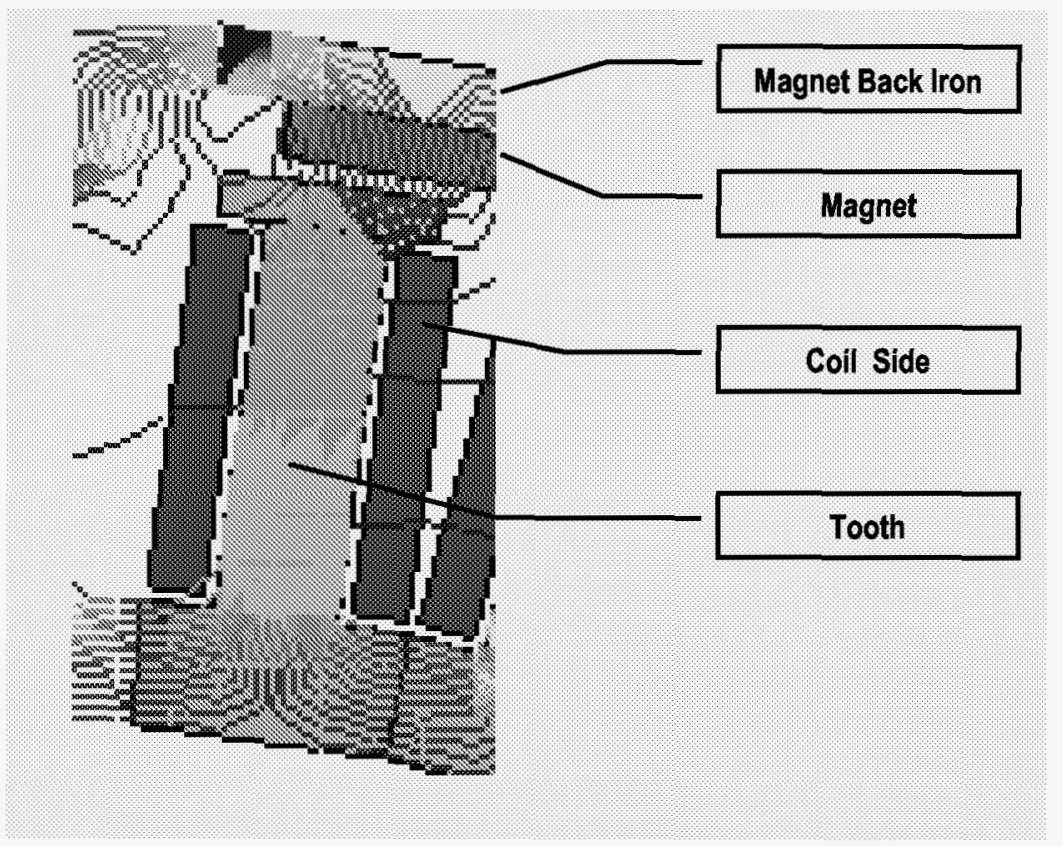

Figure 6: Partial View of Modeled Section 


\subsubsection{Magneto Flux Linkage Analysis Results}

Plots of total phase A, B and C flux linkage in one of the phase belts, as shown in Figure 7 , demonstrated that the design achieves low distortion, near-sinusoidal waveforms.

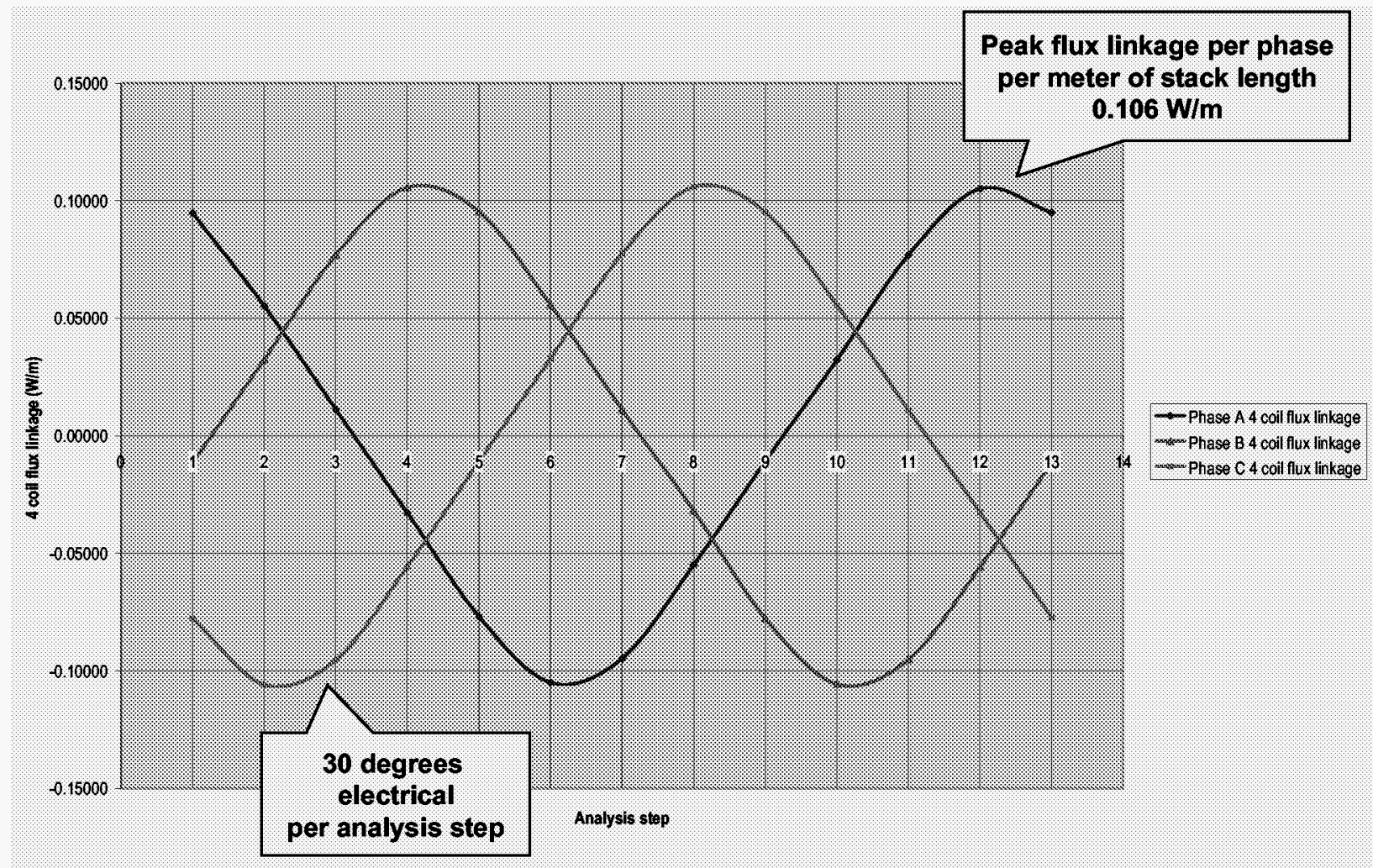

Figure 7: Phase A, B and C Flux Linkage

Open circuit voltage was derived from the Magneto flux linkage analysis and was in good agreement with the value specified in the MathCAD design procedure.

- MathCAD specified a desired open-circuit line-neutral voltage of $277 \mathrm{~V}_{\mathrm{rms}}$

- Magneto found $254 \mathrm{~V}_{\mathrm{rms}} \sim 0.92 \mathrm{pu}$ of the desired value assumed for the MathCAD analysis

- Lower Magneto result can be attributed to

- mmf drops in core and magnet back iron not included in MathCAD model

- Magneto analysis tolerance

- This discrepancy can be resolved during detail design of a prototype

- Any open circuit voltage shortfall can be corrected

- Add a small number of additional coil turns - slot area is available for additional turns

- Increase magnet strength or magnet thickness 


\subsubsection{Magneto Cogging Torque Analysis Results}

Cogging torque was estimated by Magneto analysis over half a pole pitch with zero coil current with a 2.5 degree electrical analysis interval.

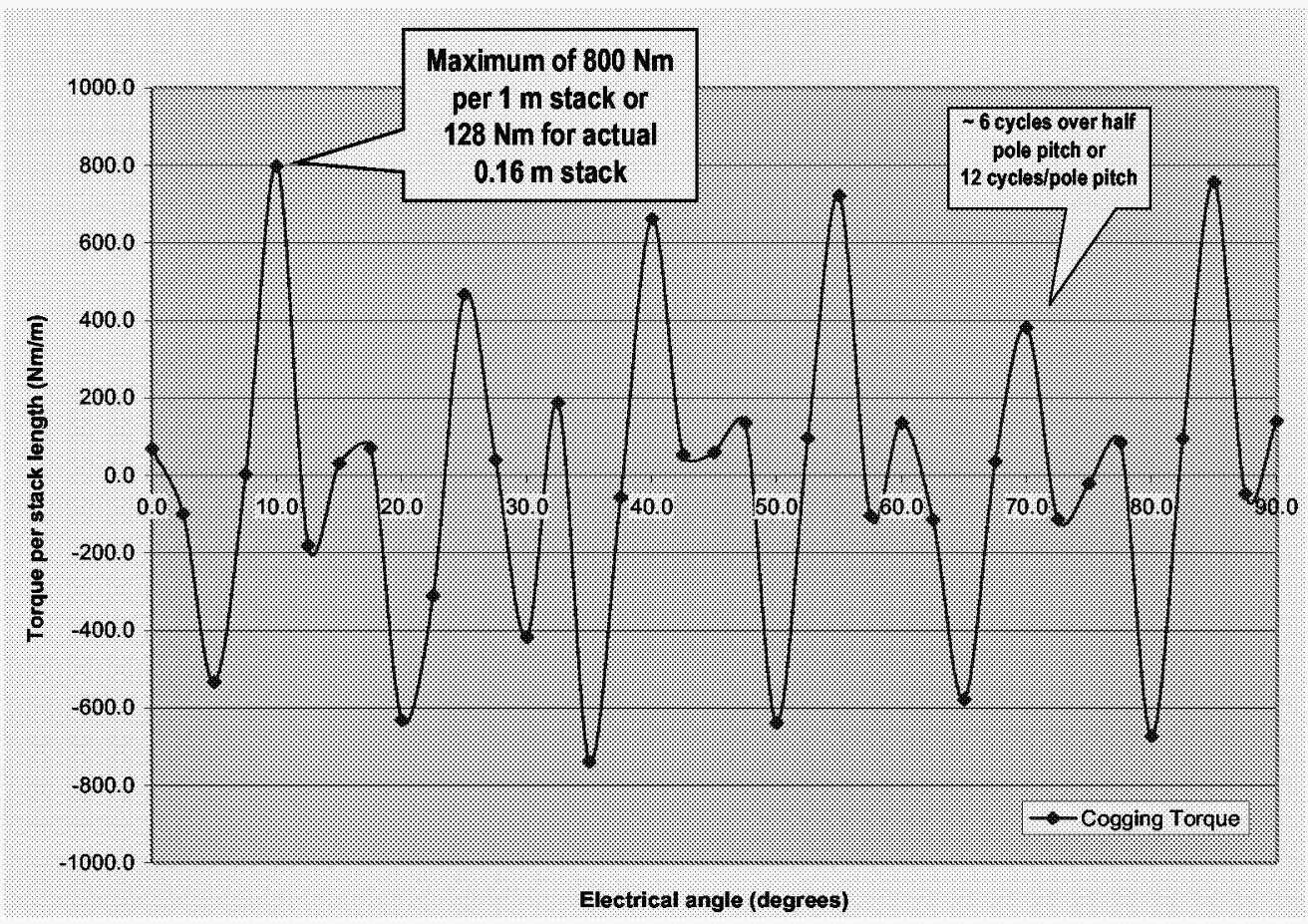

Figure 8: Cogging Torque

Peak cogging torque, as depicted in Figure 8 , was only $3 \%$ of the $4,777 \mathrm{Nm}$ rated torque a very small value for a low start up wind speed condition to overcome.

\subsubsection{Magneto Electromagnetic Reaction Torque Analysis Results}

Electromagnetic reaction torque analysis was expedited by use of an automated parametric procedure.

- Torque computed for 12 positions of the rotor with respect to the armature

- Rotated rotor 30 degrees electrical CCW per analysis step

- Stepped through rotation of one pole-pair pitch

- Armature coil side amplitudes and directions were adjusted at each step

- Accounted for sinusoidal current amplitude variation with rotation

- Accounted for 120 degree shift between phases

- Adjusted initial position of rotor to obtain maximum torque-per-ampere

- Solved for Electromagnetic Reaction Torque at Each Step 
With the initial rotor orientation set for maximum torque-per-ampere the average reaction torque and torque ripple was determined (Figure 9).

- Average torque was $15 \%$ lower than predicted with MathCAD

- Peak torque ripple was less than $3 \%$ of the average and at this level is not likely to cause any significant structural vibration

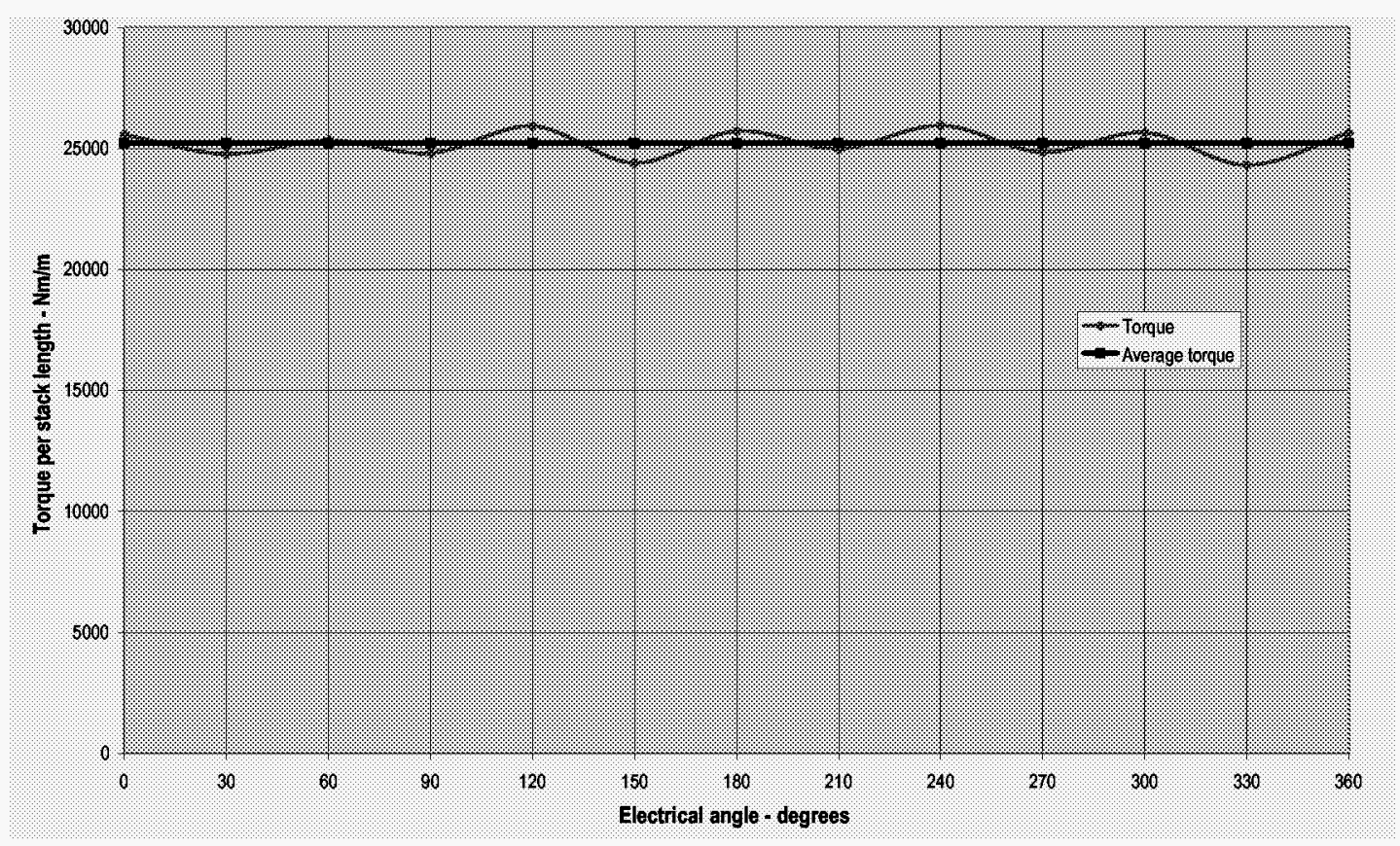

Figure 9: Electromagnetic Reaction Torque Ripple

The average reaction torque reported by the initial magneto analysis was lower than predicted by the MathCAD design procedure.

- Rationale

- MathCAD procedure does not evaluate mmf drops in the armature core and field magnet back iron

- Magneto revealed reaction torque limited by core saturation, especially in tooth tip region

- Magneto core material model not defined beyond $1.8 \mathrm{~T}$

- Solutions

- Modified Magneto core model - M45 core steel induction is not limited to 1.8 T

- $\quad$ Redesigned tooth tip section to minimize saturation effects

- Increased slot mmf by adding coil turns - small efficiency and reactance penalty

We implemented the solutions and obtained the desired reaction torque. 


\subsection{Task 5 - Prepare Drawing Package}

Drawings of the leading design candidate were developed using Pro/Engineer ${ }^{\mathrm{TM}}$ to illustrate the concepts and to facilitate solicitation of cost estimates for magnet, core module and coil components. Illustrative portions of these drawings are depicted in Figure 10.

- Armature

- Core, coil and module assembly

- Modular armature assembly

- Field

- Field magnet and back iron assembly

- Package concepts

- Armature and rotor assembly

- Housing and bearings

- Illustrative wind turbine integration

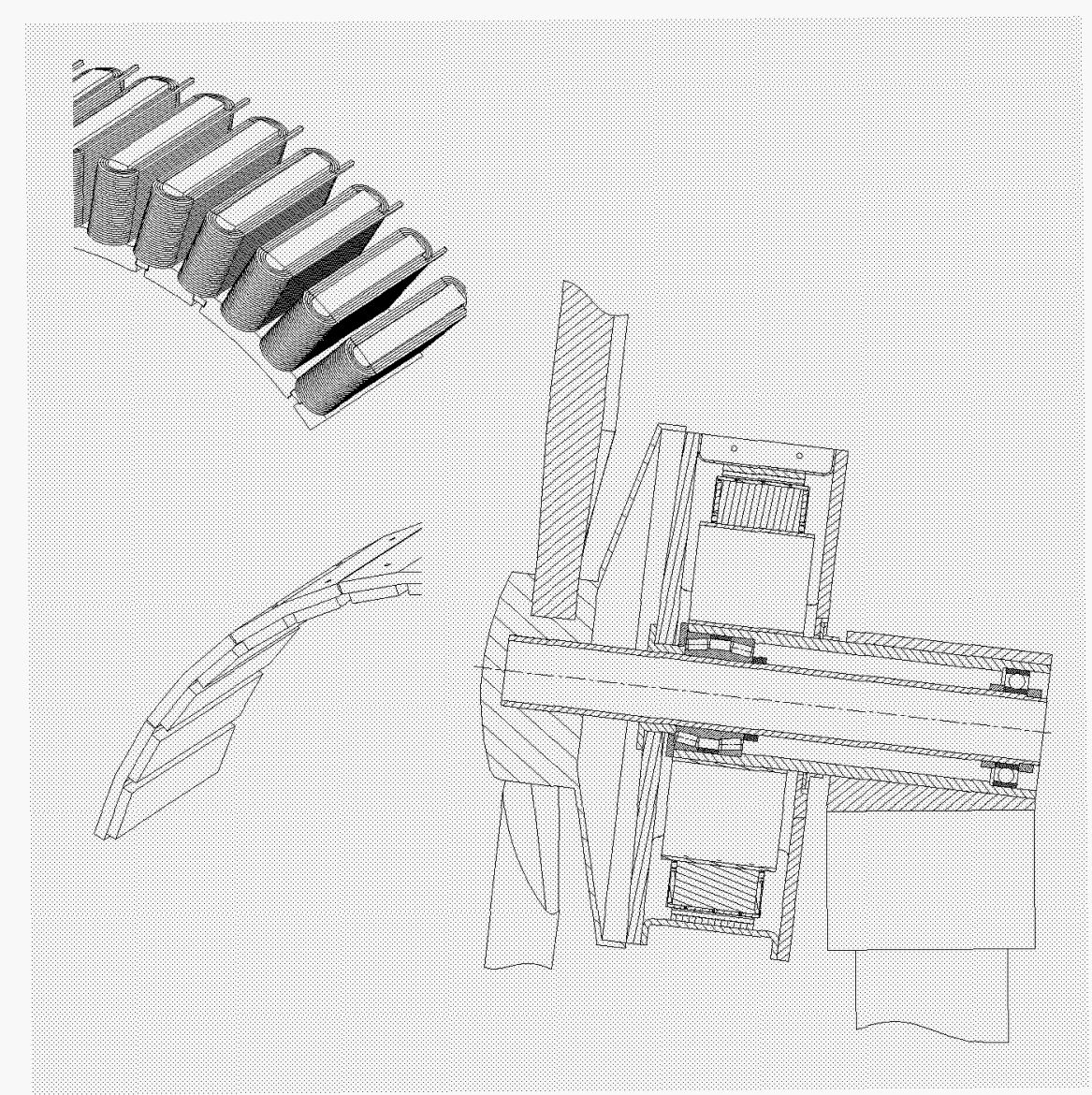

Figure 10: Pro/E Drawings of Armature, Field, and Packaging 


\subsection{Task 6 - Extrapolate Results}

We estimated the size, weight and cost of magnet, core and winding materials for the 25 and $100 \mathrm{~kW}$ ratings.

- Variable Parameters

- $\quad$ Rated power -25 and $100 \mathrm{~kW}$

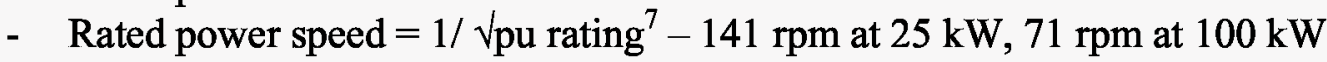

- Common Parameters for All Ratings

- Efficiency

- Synchronous reactance

- Open circuit voltage

- Magnet material properties

- Core material properties

The $50 \mathrm{~kW}$ design was extrapolated to 25 and $100 \mathrm{~kW}$ ratings with similar efficiency and synchronous reactance. Configuration data is identified in Table 6 . Note that the per unit reaction torques -- normalized by the $50 \mathrm{~kW}$ result -- predicted by the MathCAD analytic design tool are in close agreement with the classical $\mathrm{P}=\mathrm{k} \mathrm{D}^{2} \mathrm{~L}$ scaling rule for electrical machines.

Table 6: Configurations for 25 and $100 \mathrm{~kW}$ Sizes

\begin{tabular}{|c|c|c|c|c|c|}
\hline \multirow{14}{*}{ Inputs } & Parameter & \multicolumn{3}{|c|}{ Value } & \multirow{2}{*}{$\frac{\text { Units }}{\mathrm{kW}}$} \\
\hline & Power & 25 & 50 & 100 & \\
\hline & Speed & 141 & 100 & 71 & rpm \\
\hline & Reaction Torque & $1.7(0.35)$ & $4.8(1.0)$ & $13.5(2.8)$ & $\mathrm{kNm}(\mathrm{pu})$ \\
\hline & Air Gap Width & 2.5 & 3.0 & 4.0 & $\mathrm{~mm}$ \\
\hline & Air Gap Diameter & 0.64 & 0.8 & 1.0 & $\mathbf{m}$ \\
\hline & Air Gap Length L & 0.1 & 0.16 & 0.26 & $\mathrm{~m}$ \\
\hline & $\mathrm{D}^{2} \mathrm{~L}$ Metric & 0.4 & 1.0 & 2.5 & $\mathrm{pu}$ \\
\hline & Slot Depth & 52 & 62 & 62 & $\mathrm{~mm}$ \\
\hline & Current Density & 450 & 400 & 400 & $\mathrm{~A} / \mathrm{cm}^{2}$ \\
\hline & Max Core Flux Density & 1.8 & 1.8 & 1.8 & $\mathrm{~T}$ \\
\hline & Magnet $\mathrm{Br}$ & 11,000 & 11,000 & 11,000 & $\mathbf{G}$ \\
\hline & Magnet $\mathrm{Hc}$ & 10,200 & 10,200 & 10,200 & $\mathrm{Oe}$ \\
\hline & Core & 24 & 24 & 24 & $\mathrm{Ga}, \mathrm{M} 45$ \\
\hline \multirow{4}{*}{ Outputs } & Parameter & \multicolumn{3}{|c|}{ Value } & Units \\
\hline & Efficiency & 95.2 & 95.6 & 95.3 & $\%$ \\
\hline & $\begin{array}{l}\text { Synchronous } \\
\text { Reactance }\end{array}$ & 0.64 & 0.68 & 0.68 & $\mathrm{Pu}$ \\
\hline & Weight (EM Materials) & $94(0.41)$ & $228(1.0)$ & $507(2.2)$ & $\mathrm{kg}(\mathrm{pu})$ \\
\hline
\end{tabular}

${ }^{7}$ Per unit $(\mathrm{pu})$ base $=50 \mathrm{~kW}$ 


\subsection{Task 7 - Preliminary Manufacturing Cost Analysis and Power Electronic System Requirements}

\subsubsection{Factory Cost Analysis}

A factory cost analysis was performed for a $50 \mathrm{~kW}$ rated PMG and found a total of $\$ 3,500(\$ 70 / \mathrm{kW})$ at a $500 \mathrm{unit} /$ year production rate. Cost components are identified by Figure 11.

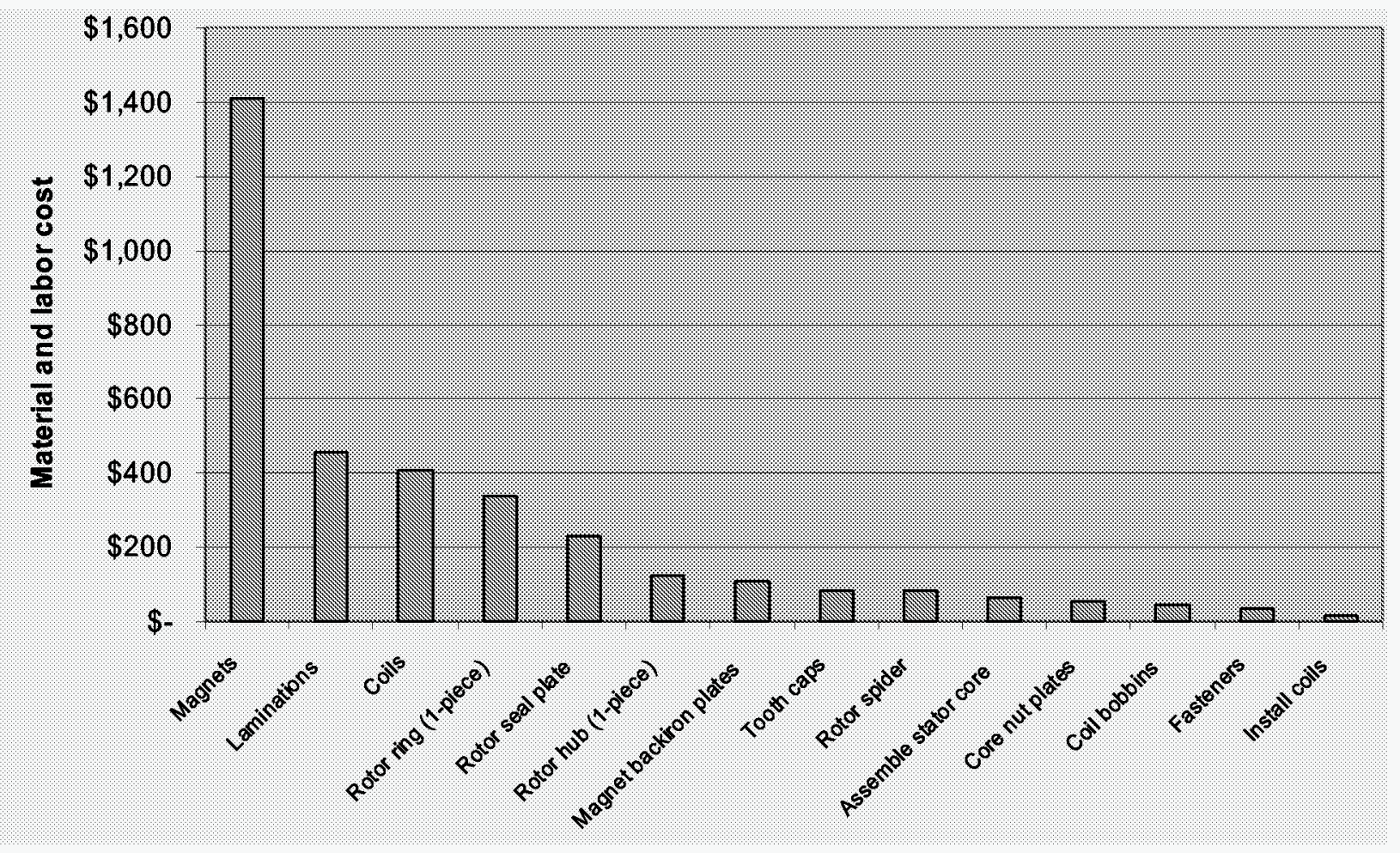

Figure 11: Factory Cost Analysis

Cost and performance tradeoffs are envisioned to achieve an optimal design for a specific wind turbine design and operating wind regime characteristics.

- Magnet cost can be traded for higher reactance and lower efficiency

- Cost and performance tradeoffs would be determined by life cycle COE analysis

\subsubsection{Analysis of Manufacturing Cost Sensitivity to Production Rate}

We also conducted a sensitivity of manufacturing cost to production rate the results of which are depicted in Figure 12. 


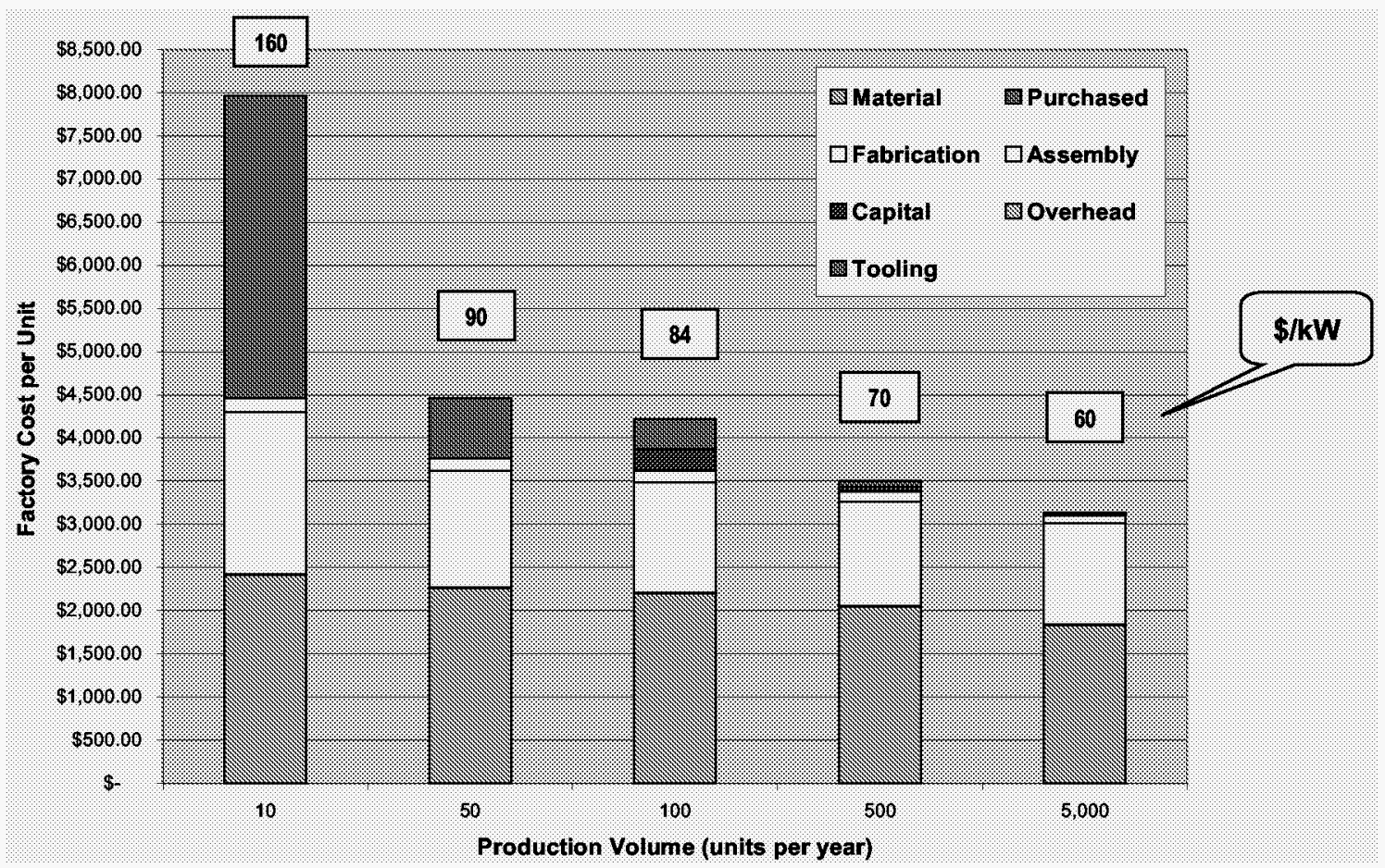

Figure 12: Sensitivity of Manufacturing Cost to Production Rate

At 500 units/year the component fabrication and final assembly labor is approximately $43 \%$ of total. Tooling capital cost $(\$ 175,000)$ amortized over 5 years is negligible.

\subsubsection{Extrapolation of Manufacturing Cost to smaller and larger ratings}

Manufacturing cost was extrapolated to 25 and $100 \mathrm{~kW}$ ratings. Results are shown in Table 7. The magnet, core and coil weights reported by MathCAD for 25 and $100 \mathrm{~kW}$ ratings used to scale cost of $50 \mathrm{~kW}$ PMG electromagnetic materials. The structural materials and labor ("other") proportional to $50 \mathrm{~kW}$ reaction torque rating.

Table 7: Manufacturing Costs as A Function of Power Rating

\begin{tabular}{|c|c|c|c|}
\hline & \multicolumn{3}{|c|}{ Costs (\$) Based on $50 \mathrm{~kW}$} \\
\hline & $25 \mathrm{~kW}$ & $50 \mathrm{~kW}$ & $100 \mathrm{~kW}$ \\
\hline Magnets & 550 & 1,409 & 3,579 \\
\hline Core & 192 & 457 & 978 \\
\hline Coils & 171 & 406 & 869 \\
\hline EM Total & 913 & 2,272 & 5,426 \\
\hline Other & 491 & 1,228 & 3,684 \\
\hline Total (\$) & 1,400 & $\mathbf{3 , 5 0 0}$ & 9,100 \\
\hline Total \$ (pu) & 0.4 & 1.0 & 2.6 \\
\hline Total $(\$ / \mathrm{kW})$ & 56 & 70 & 91 \\
\hline$\$ / \mathbf{k W}(\mathrm{pu})$ & 0.8 & 1.0 & 1.3 \\
\hline
\end{tabular}




\subsubsection{Comparable Manufacturing Cost for a Conventional Non-Modular PMG}

An illustrative non-modular $50 \mathrm{~kW}$ PMG design was developed using the MathCAD design procedure for comparison with the modular approach. The assumed key design parameters and findings are reported in Table 8.

\section{Table 8: Non-Modular 50 kW Design Configuration}

\begin{tabular}{|l|l|}
\hline \multicolumn{2}{|l|}{ Salient Design Changes } \\
\hline $3.4 \times$ as many slots & Leads to very narrow slots \\
\hline 1.5 vs $2.0 \mathrm{~mm}$ slot liner thickness & Minimize slot liner impact on slot fill with narrow slots \\
\hline 50 vs $70 \%$ slot fill & Precision bobbin wound coils cannot be employed \\
\hline 1.0 vs $0.8 \mathrm{~m}$ air gap diameter & Make up power shortfall due to lower slot fill \\
\hline
\end{tabular}

\begin{tabular}{|l|l|}
\hline Key Findings \\
\hline EM material weight much greater & Magnet $1.3 \mathrm{x}$, core $1.5 \mathrm{x}$, copper $1.1 \mathrm{x}$ \\
\hline Small efficiency loss & 94.8 vs $95.6 \%$ \\
\hline Lower synchronous reactance & 0.36 vs $0.68 \mathrm{pu}$ \\
\hline
\end{tabular}

Manufacturing cost was then extrapolated for the non-modular $50 \mathrm{~kW}$ PMG. For purposes of this analysis we made the following assumptions:

- Magnet, core and coil weights reported by MathCAD used to determine cost of electromagnetic (EM) materials

- Structural materials and labor ("other") scaled by increase of air gap diameter (1.2x) and stack length $(1.06 \mathrm{x})$ - a total factor of $1.27 \mathrm{x}$

Results of the analysis are reported in Table 9.

Table 9: Modular/Non-Modular Costs

\begin{tabular}{|l|l|l|}
\hline \multicolumn{2}{|c|}{ Costs (\$) } \\
\hline & Modular & Non-Modular \\
\hline Magnets & 1,409 & 1,860 \\
\hline Core & 457 & 663 \\
\hline Coils & 406 & 447 \\
\hline EM Total & 2,272 & 2,970 \\
\hline Other & 1,228 & 1,560 \\
\hline Total $(\$)$ & 3,500 & 4,530 \\
\hline Total \$ (pu) & 1.0 & 1.3 \\
\hline
\end{tabular}

The non-modular design is

- $1.3 \mathrm{x}$ more costly

- $20 \%$ larger in diameter

- $1.3 x$ heavier

Finally, we compared the characteristics of the Bergey $50 \mathrm{~kW}$ PMG (provided to TIAX by NREL) with those of the TIAX $50 \mathrm{~kW}$ modular design. Comparison data is identified in Table 10. 
Table 10: Characteristics of Bergey XL.50 and TIAX Design

\begin{tabular}{|l|l|l|l|}
\hline Parameter & Bergey & TIAX & Units \\
\hline Rating Speed & 105 & 100 & rpm \\
\hline Overall Diameter & 1.22 & 0.84 & $\mathrm{~m}$ \\
\hline Efficiency & 93 & 95.6 & $\%$ \\
\hline Synchronous reactance & 0.35 & 0.68 & $\mathrm{pu}$ \\
\hline
\end{tabular}

The TIAX modular PMG is smaller and more efficient but has a higher synchronous reactance, which can be accommodated with an active rectifier. The weight of the Bergey unit was not available for comparison.

\subsubsection{Power Electronic System Requirements}

Power electronic system requirements for grid-connected operation of a TIAX modular PMG will be similar to those for non-modular designs.

- Common PMG converter requirements

- Power capacity Full PMG rating

- Peak voltage Accommodate $1.5 x$ over speed voltage

- DC link voltage Boost function to stabilize link voltage for VSWT mode

- Common grid inverter requirements

- Power capacity Full PMG rating

- Voltage rating

- Power quality

- Protection

- Different modular PMG converter requirements

- Rectifier Active rectifier to accommodate higher PMG reactance

- Current RatingSupport PMG rated power and VAR demand

Active rectifier control, required to accommodate higher PMG reactance, avoids a separate boost converter to stabilize DC link voltage and is expected to have minor impact on life-cycle COE. A controlled rectifier also provides reaction torque control and turbine start up capabilities for stall controlled machines. ${ }^{8}$

\footnotetext{
${ }^{8}$ The use of am active rectifier for compensation of wind turbine PMG synchronous reactance has been investigated by A. Grauers et al., [9]. Alternative series capacitor compensation of PMG synchronous reactance has been investigated by Muljadi, et al., [10] and Grauers, et al., [11].
} 


\subsection{Annual Cost Savings}

A simple analysis was performed to determine the potential cost savings that could be realized by manufacturing small wind turbines using the modular PMG design. The projected lower cost of the modular PMG design would in turn lower the initial cost of the wind turbine. $A$ value of $\$ 150 / \mathrm{kW}$ was assumed for the generator cost to the end user of a typical small direct-drive wind turbine. Therefore, the inital cost for the generator for a nominal $50 \mathrm{~kW}$ unit is estimated at $\$ 7,500$. The estimated cost savings for the modular design is $23 \%$, hence the savings would be $0.23 \times \$ 7,500=\$ 1,700$ per unit.

The AWEA study (Reference 6) was used to estimate the number of wind turbines sold. On page 4, it is stated that 13,400 small wind turbines were sold in 2001. Assuming that $20 \%$ of those turbines will employ the modular PMG design, then 2,600 units will be sold per year. Hence, the projected annual savings to end users based on current production is 2,600 units $\times \$ 1,700$ per unit $=\$ 4.4$ Million.

On page 17 of the AWEA study, Table 5, the US market for small turbines is projected thru 2020. Assuming that half of the Commercial Buildings (Avg size is $25 \mathrm{~kW}$ ) will be above $25 \mathrm{~kW}$, the sum of the Commercial Buildings and Public Facilities (Avg size is 50 $\mathrm{kW}$ ) will be about 500,000 units. This is over roughly a 20 year period (the study dates from June 2002), so the projected future production is 25,000 units per year. Assuming that $20 \%$ of the turbines will employ the modular PMG design, the annual savings to end users for future production is $25,000 \times 0.2 \times \$ 1,700=\$ 8.5$ Million. 


\subsection{Conclusions and Recommendations}

\subsection{Conclusions}

The TIAX modular PMG design achieves the program objectives of reducing size, weight and cost without compromising efficiency.

- Cost and weight are $23 \%$ less than a non-modular design

- Overall diameter is $31 \%$ less than an existing PMG

- Efficiency is $2.5 \%$ higher than an existing PMG

- Robust bobbin wound coils expected to be more reliable

- Design scales well in the range of 25 to $100 \mathrm{~kW}$

- Higher synchronous reactance accommodated by an active rectifier

The annual cost savings associated with employing the modular PMG was estimated to range from $\$ 4.4$ million to $\$ 8.5$ million based on AWEA data for the number of turbines sold.

\subsection{Recommendations}

TIAX recommends demonstrating the weight and cost advantages of the modular PMG in a follow-on program. The program would consist of the following major tasks.

- Design Refinement

- Thermal analysis - include magnet eddy current loss

- Structural analysis

- Design for manufacture

- Build and Test Prototype

- Laser cut prototype core laminations

- Final assembly and check out tests at TIAX - open circuit voltage, static torque

- Dynamometer Test at NREL

- Install and Field Test

- Prospective wind turbine manufacturer partner

- NREL test site wind turbine 


\subsection{References}

[1] Liwschitz-Garik and Whipple, AC Machines, Van Nostrand, 1946

[2] Lipo, T.A., Introduction to AC Machine Design, Wisconsin Power electronics Research Center, University of Wisconsin, 1996

[3] Hendershot, J.R., Design of Brushless Permanent Magnet Motors, Magna Physics Corporation, 1992

[4] Grauers, A., Design of Direct-Driven Permanent Magnet Generators for Wind Turbines, Chalmers Technical University, Report 292, October `1996

[5] Mapes \& Sprowl Steel LTD, maximum core loss table

[6] AWEA Small Wind Turbine Committee, Roadmap - A 20-year industry plan for small wind turbine technology, June 2002.

[7] NREL Report No. SR-500-33196, Alternative Dsign Study Report: WindPACT Advanced Wind Turbine Drive Train Designs Study, Nov. 1, 2000 - Feb. 28, 2002

[8] Jack, A.G., et al., Permanent-Magnet Machines with Powdered Iron Cores and Pre-pressed Windings, IEEE Transactions on Industrial Appilcations, Vol. 36, No. 4, July/August 2000

[9] Grauers, A., Landstrom, S., The Rectifier's Influence on the Size of Direct-driven Generators, Department of Electric Power Engineering, Chalmers University of Technology, SE-412 96 Goteborg, Sweden, Tel. +46-31 7721637

[10] Muljadi, E., et al., Analysis of Permanent Magnet Generator for Wind Power Battery Charging, National Wind Technology Center, National Renewable Energy Laboratory, Golden, CO

[11] Grauers, A., Lindskog, A., PM Generator with Series Compensated Diode Rectifier, Department of Electric Power Engineering, Chalmers University of Technology, SE-412 96 Goteborg, Sweden, Tel. +46-31 7721637 